\title{
Assessing Exotic Plant Distribution, Abundance, and Impact at Montezuma Castle and Tuzigoot National Monuments in Arizona
}

\author{
Theresa M. Crimmins, Melissa S. Mauzy and Sarah E. Studd
}

\begin{abstract}
Exotic plants are invading federal lands at an estimated rate of 1,862 ha each day, reducing the natural diversity many of these places were set aside to protect. Effective invasive species management must be based on thorough knowledge of these species' locations and distributions, modes and rates of spread, potential and known effects, and control methods. We mapped the location and distribution of 50 exotic plant species in two Arizona national monuments using state-ofthe-art GIS and GPS technologies. The Alien Plants Ranking System was used to prioritize species for management and develop an exotic plant management plan for the park units. Other project goals included testing the efficacy of roaming surveys for exotic plant mapping using standards suggested by the North American Weed Management Association and creating a basis for future monitoring of weed populations. Mapping weeds digitally offers many advantages including increased speed and accuracy, enhanced data sharing capabilities, and easy updates, all of which aid in establishing management priorities and providing a baseline for future monitoring efforts.
\end{abstract}

Keywords: Arizona, geographic information systems, global positioning systems, handheld mapping, invasive species.

W ithin U.S. national parks, exotic plants are invading at an estimated rate of 1,862 new hectares each day, reducing the natural diversity these places were set aside to protect (NPS 1996). The number of invasive exotic plant species in the Sonoran Desert region of Arizona is currently estimated at 350, the majority of which are perennial grasses and annual plants (Tellman 2002). The most aggressive and competitive of these species can have major impacts on nutrient cycling, disturbance regimes, and community composition (Chapin et al. 1996, Mack and D'Antonio 1998, Brooks et al. 2004).

According to National Park Service (NPS) Management Policies (2000), "exotic species will not be allowed to

Ecological Restoration Vol. 26, No. 1, 2008 ISSN 1522-4740 E-ISSN 1543-4079 @2008 by the Board of Regents of the University of Wisconsin System. displace native species if displacement can be prevented." In addition, these policies state that "high priority will be given to managing exotic species that have, or potentially could have, a substantial impact on park resources, and that can reasonably be expected to be successfully controllable."

We report on an effort to make effective management recommendations for 50 exotic plant species in two national monuments in central Arizona, Montezuma Castle and Tuzigoot National Monuments. We accomplished this through 1) a comprehensive digital mapping effort; 2) implementation of a plant priority ranking system; and 3) development of an exotic plant management plan. Our intent is that the information collected through this effort will increase the ability of resource managers to analyze and prioritize invasive plant management needs, and serve as a baseline for long-term monitoring of invasive exotic plants.

\section{Digital Weed Mapping}

Managing exotic species is resource intensive, requiring a long term commitment (Hiebert 1997) and a thorough knowledge of introduced species' modes and rates of spread, potential and known effects, and control methods (Wittenberg and Cock 2001). Exotic plant distributions have successfully been mapped by means of aerial survey (e.g., Everitt et al. 1996, Birdsall et al. 1997), global positioning systems (GPS) in the field (e.g., Anderson et al. 1996, Webster et al. 2000), remote sensing techniques (e.g., Carson et al. 1995, Underwood et al. 2003), and traditional plant sampling techniques (e.g., Jurado-Exposito et al. 2003).

Handheld computers are becoming a more common exotic plant mapping technique, as evidenced by The Nature Conservancy's Weed Information Management System (http://tncweeds. ucdavis.edu/wims.html), designed to 


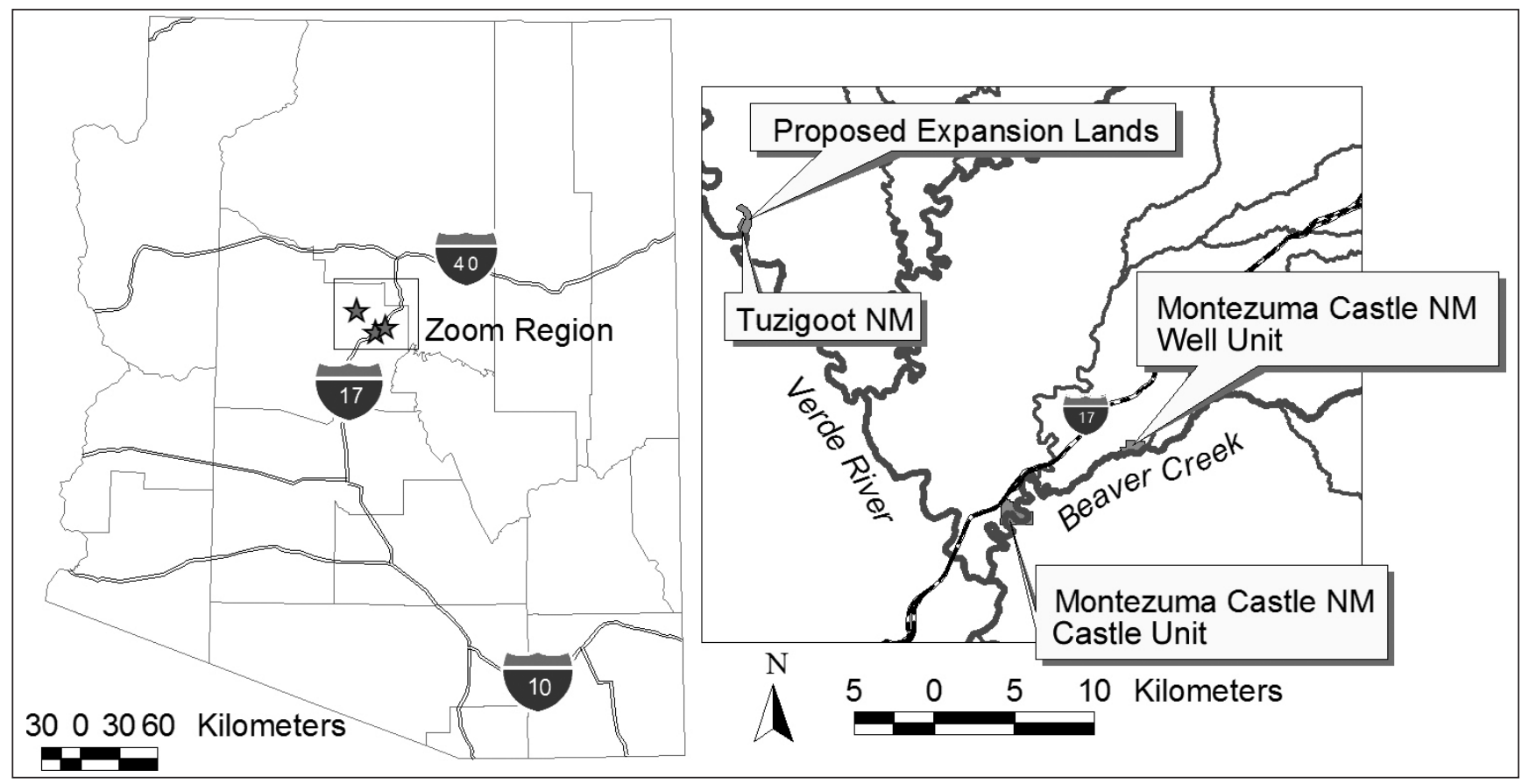

Figure 1. Location of Montezuma Castle and Tuzigoot National Monuments, Arizona.

work on handheld computers, and the growing number of studies employing these technologies (e.g., Ayres et al. 2004, Mau-Crimmins and Orr 2005, Adair et al. 2006). Mapping weeds digitally offers many advantages over traditional paper-based methods including increased speed and accuracy, enhanced data sharing capabilities, and easy updates, as well as aiding in the establishment of management priorities (Mau-Crimmins and Orr 2005).

\section{Study site and field mapping techniques}

Montezuma Castle and Tuzigoot National Monuments are located in central Arizona's Verde Valley, midway between the cities of Flagstaff and Phoenix (Figure 1). Montezuma Castle National Monument comprises two units, the main 231-ha castle unit (MCCU), and a smaller 103-ha unit containing a limestone cavern known as the "well" (MCWU). Nearby Tuzigoot National Monument (TNM) encompasses 17.6 ha. An additional 38-ha section adjacent to the park's eastern border and encompassing Tavasci Marsh has been proposed as an expansion of TNM, and we included this area in our 2004 weed surveys.
We worked from a list of 50 of the most problematic exotic plant species that had been generated previously via a query to park resource management staff (Halvorson and Guertin 2003). We then mapped the location and abundance of these species following the North American Invasive Plant Mapping Standards (NAWMA 2002) and the "Beyond NAWMA" guidelines suggested by researchers at the United States Geological Survey and Colorado State University (Stohlgren et al. 2003). The NAWMA system provides a standardized format for collecting data and mapping non-native plant species, and these standards have been widely adopted by organizations including the U.S. Forest Service, National Park Service, and Fish and Wildlife Service. The "Beyond NAWMA" guidelines add to these minimum standards by providing additional tools that incorporate quality assurance and levels of uncertainty in data collection.

Because the parks to be mapped were small (less than $500 \mathrm{ha}$ ), we were able to carry out an intensive mapping method and inventoried both park units in 2003 and 2004. We undertook roaming surveys, which involved walking cross-country to locate target plants, as opposed to following a formal sampling design. Base park GIS layers and high-resolution aerial photographs of park units were loaded onto handheld computers. Using the computers and GPS units, we mapped individual target plants and patches of plants smaller than $5 \mathrm{~m}$ in diameter as points. We mapped larger patches as polygons. Since the GPS units were WAAS-enabled for greater accuracy, spatial resolution was assumed to be better than $5 \mathrm{~m}$ (Garmin International 2001); this guided our differentiation between points and small patches. Spatial location, distribution, and abundance of these plants were recorded as ArcView shapefiles (.shp) via roaming surveys using Compaq iPAQ 3950 pocket $P C$ s equipped with StarPal HGIS software version 5.01 attached to Garmin V GPS units. Data were collected only when GPS units were receiving signals from at least four satellites and when PDOP was less than seven.

Up to five species were recorded for each polygon, in descending order of invasion by target species. Abundance of target species was recorded for polygons in the following cover 
classes: $<1 \%, 1-5 \%, 6-25 \%, 26-50 \%$, 51-75\%, 76-95\%, and 96-100\%. Data files were split and merged to generate individual ArcView shapefiles by species by park unit, with points and polygons appearing in separate files.

The actual land area infested by each target species was calculated using polygon data by multiplying the cover class midpoint by the polygon's area. For example, a polygon 1.5 ha in area estimated at $25-50 \%$ cover would represent 0.5625 ha $(1.5 \times 0.375=$ $0.5625 \mathrm{ha}$ ) infested. Points were estimated to represent $0.5 \mathrm{~m}^{2}$; these values were added to those calculated from these polygons (Table 1).

\section{Circular plot sampling}

In the "Beyond NAWMA" guidelines, Stohlgren et al. (2003) recommend supplementing roaming surveys with randomly located circular sample plots in order to estimate spatial bias and the accuracy of cover estimates. Following these recommendations, we allocated approximately $10 \%$ of our total field time to sampling circular plots in 2003; 7\% was allocated in 2004. The circular plots were $7.32 \mathrm{~m}$ in diameter, encompassing three $1-\mathrm{m}^{2}$ quadrats (Stohlgren et al. 2003). Percent cover of all target exotic species was recorded within the $1-\mathrm{m}^{2}$ quadrats to the nearest $1 \%$. All additional species observed within the entire circular plot were also recorded. Relative abundance was calculated for each species using both roaming surveys and circular plots. To remove skew, both datasets were transformed using a cube-root transformation. We used a Pearson's $r$ correlation to compare estimates of relative abundance for species in common between the two methods. The 2003 and 2004 datasets were analyzed separately because time and funding constraints resulted in different distributions and numbers of circular plots (53 in 2003 and 30 in 2004) each year.

\section{Alien Plants Ranking System}

We prioritized target plant species using the Alien Plants Ranking System version 7.1 (APRS Implementation Team 2001). Invasive species distribution, abundance, phenology, and morphology data were collected through the fieldwork and an extensive literature review. We compiled our results in a project-specific database and then entered them into the APRS database for ranking.

The APRS is divided into two main sections: significance of impact and feasibility of control. The impact category is further divided into two subcategories: significance of impact and innate ability of species to become a pest. For each of the categories of control, impact, and pest, each plant is ranked on a scale of 1 to 100 . The rankings then were the basis for management recommendations and the Exotic Plant Management Plan for the two parks.

\section{Survey Results}

Of the 50 species identified in our query of park managers, we encountered 33 during 2003 roaming surveys in at least one of the three park units. Each species distribution was mapped as points or polygons in 2003 (Table 1). In the 2004 season, 33 species were mapped; of these, 26 were encountered in both seasons. Five additional invasive exotic species not included on the original list of 50 species were also encountered (AZWIPWG 2005). Approximately 360 person-hours in 2003 and 300 person-hours in 2004 were spent in the field collecting data and about 60 hours were spent in the office compiling data and preparing metadata and maps. Final datasets were uploaded to a regional weeds database to enhance regional data sharing (Southwest Exotic Mapping Program http://sbsc.wr.usgs.gov/research/ projects/swepic/swemp/swempA. asp).

\section{Circular plots}

The Pearson's $r$ correlation between the relative abundance of target species collected via circular plots compared to roaming surveys in 2003 yielded an $R^{2}$ value of $0.76(p \leq 0.0001)$. Roaming survey estimates of percent cover were slightly higher than circular plots. This may be the result of differences in precision, since the roaming surveys relied on broad cover classes and circular plots estimated percent cover to the nearest $1 \%$. We saw a positive but slightly weaker relationship between roaming survey and circular plot data in $2004\left(R^{2}=0.53, p=0.0003\right)$. This may be due to the fact that we sampled a smaller number of circular plots in 2004. Overall, these results support the conclusion that roaming surveys are effective for small park units, and that circular plots help ensure the consistency of abundance estimates made by the field observers. More than 10\% of field resources may be required in order to take advantage of circular plot sampling, however.

\section{Alien Plants Ranking System}

Of the 40 species ranked using APRS, all fell into the low and medium impact categories and ranged from easy to difficult to control (Figure 2). On the 100 -point scale, plants ranged from 7 to 51 for significance of impact; from 33 to 79 for innate ability to become a pest; and from 17 to 73 for feasibility of control or management.

The utility of APRS was prioritizing the target species, allowing us to make recommendations about the allocation of limited resources. As we describe below, some of the most widespread species were also found to be the most difficult to control; it was recommended that at this time, no major control efforts be exerted on these plants. Other species appeared in very small quantities but have the potential to cause large impacts; these plants were given highest priority for control. In combination with maps of species occurrences, APRS results led directly to management recommendations. 
Table 1. Land area (in ha) infested by target plant species in Montezuma Castle and Tuzigoot National Monuments and expansion lands in Arizona in 2003 and 2004. " $\mathrm{T}$ " denotes area < $0.01 \mathrm{ha}$; "-" denotes species not a target in that sampling year; * indicates native to U.S. according to USDA Plants Database (2007). Numbers indicate species listed as noxious weeds by Arizona Department of Agriculture (2005): 1 prohibited, 2 restricted, 3 regulated.

\begin{tabular}{|c|c|c|c|c|c|c|c|}
\hline Scientific Name & $\begin{array}{c}\text { MCCU } \\
2003\end{array}$ & $\begin{array}{l}\text { MCWU } \\
2003\end{array}$ & $\begin{array}{l}\text { TNM } \\
2003\end{array}$ & $\begin{array}{c}\text { MCCU } \\
2004\end{array}$ & $\begin{array}{c}\text { MCWU } \\
2004 \\
\end{array}$ & $\begin{array}{l}\text { TNM } \\
2004 \\
\end{array}$ & $\begin{array}{c}\text { TNM- } \\
\text { Expansion } 2004\end{array}$ \\
\hline Acroptilon repens (hardheads) ${ }^{1}{ }^{2}$ & - & - & - & 0 & 0 & 0 & $\mathrm{~T}$ \\
\hline Ailanthus altissima (tree of heaven) & - & - & - & $\mathrm{T}$ & 0 & 0 & $\mathrm{~T}$ \\
\hline Amaranthus palmeri (carelessweed)* & 0 & 0 & 0 & 0 & 0 & 0 & 0 \\
\hline Avena fatua (wild oat) & 0.13 & 0.09 & 0 & 0.25 & 0 & 0 & 0 \\
\hline Boerhavia coccinea (scarlet spiderling)* & $\mathrm{T}$ & 0.13 & 0 & $\mathrm{~T}$ & 0.11 & $\mathrm{~T}$ & 0.11 \\
\hline Brassica tournefortii (Sahara mustard) & $\mathrm{T}$ & 0 & 0 & 0 & 0 & 0 & 0 \\
\hline Bromus japonicus (Japanese brome) & - & - & - & 0 & 0 & 0 & $\mathrm{~T}$ \\
\hline Bromus rigidus (ripgut brome) & 0.01 & 5.07 & 0 & 20.8 & 5.97 & 0 & 0.08 \\
\hline Bromus berterianus (Chilean chess) & 0 & 0 & 0 & 0 & 0 & 0 & 0 \\
\hline Bromus rubens (red brome) & 35.2 & 20.2 & 0.68 & 54 & 21.3 & 1.89 & 6.03 \\
\hline Bromus tectorum (cheatgrass) & 10.6 & 1.16 & 0 & 9.63 & 1.45 & 0 & $\mathrm{~T}$ \\
\hline Centaurea melitensis (Maltese star-thistle) & $\mathrm{T}$ & 0 & 0 & $\mathrm{~T}$ & $\mathrm{~T}$ & 0 & $\mathrm{~T}$ \\
\hline Centaurea solstitialis (yellow star-thistle) ${ }^{1}, 2$ & 0 & 0.16 & 0 & 0 & 0 & 0 & 0 \\
\hline Chenopodium murale (nettleleaf goosefoot) & 0 & 0 & 0 & 0 & 0 & 0 & 0 \\
\hline Cynodon dactylon (Bermuda grass) & 0.12 & 0.24 & 0 & 0.03 & 0.47 & 0.04 & 0.18 \\
\hline Cyperus esculentus (chufa flatsedge) & $\mathrm{T}$ & $\mathrm{T}$ & 0 & - & - & - & - \\
\hline Descurainia sophia (Sophia) & 0 & 0 & 0 & 0 & 0 & 0 & 0 \\
\hline Digitaria sanguinalis Hairy crabgrass* & 0.01 & $\mathrm{~T}$ & 0 & $\mathrm{~T}$ & $\mathrm{~T}$ & 0 & $\mathrm{~T}$ \\
\hline Dimorphotheca sinuata (glandular cape marigold) & 0 & 0 & 0 & 0 & 0 & 0 & 0 \\
\hline Echinochloa colona (jungle rice) & 0 & 0 & 0 & - & - & - & - \\
\hline Echinochloa crus-galli (barnyard grass) & $\mathrm{T}$ & $\mathrm{T}$ & 0 & 0 & 0 & 0 & 0 \\
\hline Elaeagnus angustifolia (Russian olive) & - & - & - & 0 & 0 & 0 & $\mathrm{~T}$ \\
\hline Eragrostis cilianensis (stinkgrass) & 0 & 0 & 0 & 0 & 0 & 0 & 0 \\
\hline Eragrostis curvula (weeping lovegrass) & 0 & $\mathrm{~T}$ & 0 & 0 & 0 & 0 & 0 \\
\hline Eragrostis lehmanniana (Lehmann lovegrass) & - & - & - & 0.25 & 0 & $\mathrm{~T}$ & 0 \\
\hline Erodium cicutarium (redstem stork's bill) & 49.5 & 18.1 & 0 & 14.9 & 4.15 & 8.47 & 2.81 \\
\hline Galium aparine (stickywilly)* & 0 & 0 & 0 & 0 & 0 & 0 & 0 \\
\hline Helianthus annuus (common sunflower)* & $\mathrm{T}$ & 0.01 & 0 & - & - & - & - \\
\hline Hordeum spp. (barley) & 9.97 & 0.93 & 0 & 14.3 & 2.28 & $\mathrm{~T}$ & 2.19 \\
\hline Ipomoea purpurea (tall morning-glory) ${ }^{1}$ & 0 & 0 & 0 & 0 & 0 & 0 & 0 \\
\hline Kochia scoparia. (Mexican-fireweed) & - & - & - & 0 & 0 & 0 & 0.02 \\
\hline Lactuca serriola (prickly lettuce) & $\mathrm{T}$ & 0.12 & 0 & $\mathrm{~T}$ & $\mathrm{~T}$ & 0 & $\mathrm{~T}$ \\
\hline Laennecia coulteri (conyza)* & 0 & 0 & 0 & 0 & 0 & 0 & 0 \\
\hline Linaria dalmatica (dalmation toadflax) ${ }^{1},{ }^{2}$ & - & - & - & 0.13 & 0.13 & 0 & 0 \\
\hline Lolium perenne (perennial ryegrass) & - & - & - & $\mathrm{T}$ & 0 & 0 & 0 \\
\hline Malva parviflora (cheeseweed mallow) & 0 & 0 & 0 & 0 & 0 & 0 & 0 \\
\hline Marrubium vulgare (horehound) & $\mathrm{T}$ & 0.94 & $\mathrm{~T}$ & 0.1 & 0.19 & 0.01 & $\mathrm{~T}$ \\
\hline Medicago sp. (burclover) $)^{1,3}$ & - & - & - & 0 & 0 & 0 & 0 \\
\hline Melilotus officinalis (yellow sweetclover) & 0.01 & $\mathrm{~T}$ & 0 & $\mathrm{~T}$ & $\mathrm{~T}$ & 0 & $\mathrm{~T}$ \\
\hline Melilotus indicus (white sweetclover) & 0 & 0 & 0 & $\mathrm{~T}$ & $\mathrm{~T}$ & 0 & $\mathrm{~T}$ \\
\hline Nicotiana glauca (tree tobacco) & 0 & 0 & 0 & 0 & 0 & 0 & 0 \\
\hline Oxalis stricta (yellow oxalis)* & 0 & 0 & 0 & 0 & 0 & 0 & 0 \\
\hline Panicum antidotale (blue panicum) & 0 & 0 & 0 & 0 & 0 & 0 & 0 \\
\hline Pennisetum ciliare (buffelgrass) & 0 & 0 & 0 & 0 & 0 & 0 & 0 \\
\hline Pennisetum setaceum (crimson fountaingrass) & 0 & 0 & 0 & 0 & 0 & 0 & 0 \\
\hline Phalaris caroliniana (Carolina canarygrass)* & 0 & 0 & 0 & 0 & 0 & 0 & 0 \\
\hline Phalaris minor (littleseed canarygrass) & 0 & 0 & 0 & 0 & 0 & 0 & 0 \\
\hline Polygonum aviculare (prostrate knotweed) & $\mathrm{T}$ & 0 & 0 & $\mathrm{~T}$ & 0 & 0 & $\mathrm{~T}$ \\
\hline Polypogon monspeliensis (annual rabbitsfoot grass) & 0.01 & $\mathrm{~T}$ & 0 & $\mathrm{~T}$ & $\mathrm{~T}$ & 0 & 0.16 \\
\hline Rumex crispus (curly dock) & 0 & $\mathrm{~T}$ & 0 & $\mathrm{~T}$ & $\mathrm{~T}$ & 0 & $\mathrm{~T}$ \\
\hline Salsola kali (Russian thistle) & 0.01 & 0.09 & 0 & 2.85 & 0.09 & 0 & 1.94 \\
\hline Schismus arabicus (Arabian schismus) & 0 & 0 & 0 & 0 & 0 & 0 & 0 \\
\hline Schismus barbatus (common Mediterranean grass) & 7.88 & 0.52 & 0 & 2.83 & $\mathrm{~T}$ & $\mathrm{~T}$ & 0.05 \\
\hline Setaria viridus (green bristlegrass) & $\mathrm{T}$ & $\mathrm{T}$ & 0 & 0 & 0 & 0 & 0 \\
\hline Sisymbrium irio (London rocket) & 0.85 & 0.77 & 0.86 & 0.3 & $\mathrm{~T}$ & 0.48 & 0.79 \\
\hline Solanum elaeagnifolium (silverleaf nightshade)* & 0 & 0 & 0 & 0 & 0 & 0 & 0 \\
\hline Sonchus asper (spiny sowthistle) & - & - & - & 0 & 0.01 & 0 & $\mathrm{~T}$ \\
\hline Sorghum halepense (Johnsongrass) & 0.01 & 0.32 & 0 & $\mathrm{~T}$ & 0.31 & 0 & 0 \\
\hline Tamarix spp. (tamarisk) & 7.2 & $\mathrm{~T}$ & 0 & 0.02 & $\mathrm{~T}$ & 0 & $\mathrm{~T}$ \\
\hline Torilis arvensis (spreading hedgeparsley) & - & - & - & 0 & 0 & 0 & $\mathrm{~T}$ \\
\hline Tribulus terrestris (puncturevine) $)^{1,}{ }^{3}$ & 0 & 0 & 0 & 0 & $\mathrm{~T}$ & 0 & $\mathrm{~T}$ \\
\hline Verbascum thapsus (common mullein) & 0 & $\mathrm{~T}$ & 0 & $\mathrm{~T}$ & $\mathrm{~T}$ & 0 & 0 \\
\hline Xanthium strumarium (rough cocklebur)* & 0 & $\mathrm{~T}$ & 0 & 0.02 & $\mathrm{~T}$ & 0 & 0 \\
\hline
\end{tabular}




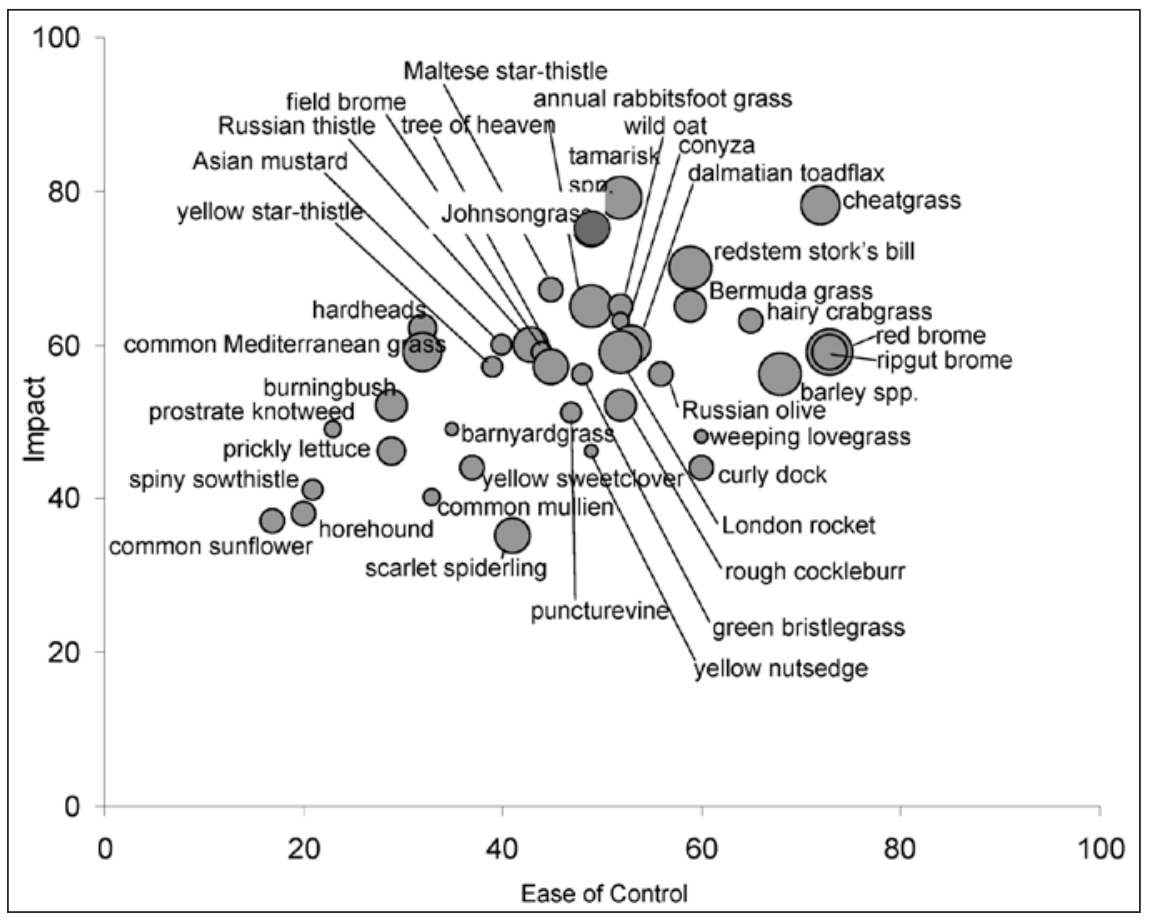

Figure 2. Plot of invasive species ranked using the Alien Plant Ranking System, showing ease of control versus level of impact. Size of dot represents the pest score on a scale from 1 to 100 .

\section{The Exotic Plant Management Plan}

Based on the results of field surveys, APRS rankings, and literature reviews, recommendations tailored for each park unit were compiled in an Exotic Plant Management Plan for the two monuments (Mau-Crimmins et al. 2005). Management recommendations were organized by regions within park units, for example, riparian corridor and uplands. Highest priority species were addressed first, followed by additional recommendations as resources become available. Comprehensive species control and life history information were compiled in an appendix to the report.

\section{Management Recommendations}

Dominant species in all surveyed park areas included red brome (Bromus rubens), redstem stork's bill (Erodium cicutarium), barley (Hordeum sp.), cheatgrass (Bromus tectorum), and ripgut brome (Bromus diandrus ssp. rigidus) (Table 1). Each of these species appears in the upper-right quadrant of the impact versus control output plot from APRS (Figure 2). These plants both have large impacts on the plant communities they invade and are difficult to control, requiring major mechanical and chemical inputs with potential for great disturbance. Several of the grasses are notoriously difficult to control and are not known to respond to herbicides (Halvorson and Guertin 2003).

The APRS ranking indicated that emphasis should be placed on controlling and removing aggressive species that have only begun to invade park units. Within MCCU and MCWU, top priority was given to tamarisk (Tamarix spp.) and tree of heaven (Ailanthus altissima) because of their potential for major impacts and small numbers (Table 1). Emphasis was also placed on reducing the many exotic species with relatively high impact scores but still in controllable numbers along the river corridors, including Dalmatian toadflax (Linaria dalmatica) and rough cockleburr (Xanthium strumarium).

Our research also suggests that management of non-native plant species at Tuzigoot National Monument should focus on preventing establishment of new non-native species rather than wasting resources working to eradicate widespread species that are difficult to control. Non-native plants including Bermudagrass (Cynodon dactylon), Lehmann lovegrass (Eragrostis lehmanniana), henbit deadnettle (Lamium amplexicaule), horehound (Marrubium vulgare), stinkgrass (Eragrostis cilianensis), and common Mediterranean grass (Schismus barbatus) have been recorded in areas where visitor and maintenance traffic is high. Several of these species have medium to low control scores (Figure 2) and intermediate to high impact scores. For these reasons, we suggested removing these individuals before they become widespread throughout the park. Within the Tavasci Marsh lands adjacent to TNM, top priority was given to eradicating three woody species present in small numbers and the potential to have major ecological impacts: tamarisk, tree of heaven, and Russian olive (Elaeagnus angustifolia).

\section{Promise of Field Methods}

To our knowledge, this represents one of the first applications of roaming surveys to exotic species mapping in Arizona. This effort served as a test of the method as well as a data-collection exercise. We concluded that handheld computer-based mapping is both an efficient and effective way to collect data. This method has many benefits including increased spatial accuracy over paper-based maps, elimination of transfer from field forms to the computer, and more efficient data collection, map creation, and report generation. The spatially explicit data lend themselves to further GIS-based analyses. We encountered few problems with the system, despite the long field days (often over ten hours) and long distances from technological support. This is commendable, considering that the two field crewmembers were inexperienced with GPS, GIS, and handheld computers at the outset of the first field season.

Given the results of the accuracy assessment, we feel the roaming 
survey approach offers a cost-effective method for producing maps of exotic species, especially for lands of this size. Additionally, the Alien Plants Ranking System is a sensible approach to prioritizing exotic species for management efforts. Advantages of the approach include the facilitation of data sharing among the parks and neighboring land management agencies, and rapid updates for tracking trends in weed populations. Datasets collected as a part of this project will serve as the baseline for future weeds monitoring and park management decisionmaking.

\section{Acknowledgments}

Thanks to Montezuma Castle and Tuzigoot NM staff; to Meg Quinn for assistance with data collection; and to Amy Tendick, Jason Welborn, and Kristen Beaupre for data management and map production. Thanks also go to the Sonoran Desert Inventory and Monitoring Program for project support and facilities.

\section{References}

Adair, R., R.C. Johnson, B. Hellier and W. Kaiser. 2006. Collecting tapertip onion (Allium acuminatum Hook.) in the Great Basin using traditional and GIS methods. Native Plants Journal 7:141-148.

Alien Plants Ranking System (APRS) Implementation Team. 2001. Alien plants ranking system version 7.1. Flagstaff, AZ: Southwest Exotic Plant Information Clearinghouse. http://sbsc. wr.usgs.gov/research/projects/swepic/ aprs/ranking.asp.

Anderson, G.L., J.H. Everitt, D.E. Escobar, N.R. Spencer and R.J. Andrascik. 1996. Mapping leafy spurge (Euphorbia esula) infestations using aerial photography and geographic information systems. Geocarta 11:81-89.

Arizona Department of Agriculture. 2005. Prohibited, regulated and restricted noxious weeds. http://www.azda.gov/ PSD/quarantine5.htm.

Arizona Wildlands Invasive Plant Working Group (AZWIPWG). 2005. Invasive non-native plants that threaten wildlands in Arizona: A categorized list developed by the Arizona Wildlands Invasive Plant Working Group. http://sbsc.wr.usgs.
gov/research/projects/swepic/SWVMA/ InvasiveNon-NativePlants That Threaten WildlandsInArizona.pdf.

Ayres, D.R., D.L. Smith, K. Zaremba, S. Klohr and D.R. Strong. 2004. Spread of exotic cordgrasses and hybrids (Spartina sp.) in the tidal marshes of San Francisco Bay, California, USA. Biological Invasions 6:221-231.

Birdsall, J.L., P.C. Quimby Jr., N.E. Rees, T.J. Svejcar and B.F. Sowell. 1997. Image analysis of leafy spurge (Euphorbia esula) cover. Weed Technology 11:798-803.

Brooks, M.L., C.M. D’Antonio, D.M. Richardson, J.B. Grace, J.E. Keeley, J.M. DiTomaso, R.J. Hobbs, M. Pellant and D. Pyke. 2004. Effects of invasive alien plants on fire regimes. BioScience 54:677-688.

Carson, H.W., L.W. Lass and R.H. Callihan. 1995. Detection of yellow hawkweed (Hieracium pratensis) with high resolution multispectral digital imagery. Weed Technology 9:477-483.

Chapin, F.S., III, H.L. Reynolds, C.M. D'Antonio and V.M. Eckhart. 1996. The functional role of species in terrestrial ecosystems. Pages 403-428 in B. Walker and W. Steffan (eds), Global Change in Terrestrial Ecosystems. Cambridge: Cambridge University Press.

Everitt, J.H., D.E. Escobar, M.A. Alaniz, M.R. Davis and J.V. Richerson. 1996. Using spatial information technologies to map Chinese tamarisk (Tamarix chinensis) infestations. Weed Science 44:194-201.

Garmin International, Inc. 2003. GPS $V$ Personal Navigator Owner's Manual and Reference Guide. Olathe, KS: Garmin International, Inc. http://www8.garmin. com/manuals/GPSV_OwnersManual. pdf.

Halvorson, W.L. and P. Guertin. 2003. USGS Weeds in the West project: Status of introduced plants in southern Arizona parks. Plant Fact Sheets prepared for Tuzigoot National Monument. Tucson, AZ: U.S. Geological Survey. http:// sdrsnet.srnr.arizona.edu/index.php? page $=$ datamenu\&lib $=2 \&$ sublib $=13$.

Hiebert, R.D. 1997. Prioritizing invasive plants and planning for management. Pages 195-214 in J.O. Luken and J.W. Theiret (eds), Assessment and Management of Plant Invasions. New York: Springer-Verlag.

Jurado-Exposito, M., F. Lopez-Granados, L. Garcia-Torres, A. Garcia-Ferrer, M. Sanchez de la Orden and S. Atenciando. 2003. Multi-species weed spatial variability and site-specific management maps in cultivated sunflower. Weed Science 51:319-328.

Mack, M.C. and C.M. D’Antonio. 1998. Impacts of biological invasions on disturbance regimes. Trends in Ecology and Evolution 13:195-198.

Mau-Crimmins, T.M. and B.J. Orr. 2005. Monitoring nonnative plants using hand-held GIS technology. Pages 298-301 in G.J. Gottfried, B.S. Gebow, L.G. Eskew and C. Edminster (eds), Biodiversity and Management of the Madrean Archipelago II. RMRS-P-36. Fort Collins, CO: U.S. Department of Agriculture, Forest Service, Rocky Mountain Research Station.

Mau-Crimmins, T., S.E. Studd and M.S. Mauzy. 2005. Exotic plant management plan for Montezuma Castle and Tuzigoot National Monuments. National Park Service Technical Report NPS/IMR/ SODN-001.

National Park Service (NPS). 1996. A strategic plan for managing invasive nonnative plants on National Park System lands. http://www.nature. nps.gov/biology/invasivespecies/ strat_pl.htm.

2000. Management policies 2001. NPS D1416. http://www.nps.gov/ refdesk/mp/.

North American Weed Management Association (NAWMA). 2002. North American invasive plant mapping standards. http://www.nawma.org/ documents/Mapping\%20Standards/ Invasive \%20Plant \%20Mapping $\% 20$ Standards.pdf.

Stohlgren, T.J., T.D. Barnett and S.S. Simonson. 2003. Beyond North American weed management standards. http://www.nawma.org/documents/ Mapping\%20Standards/BEYOND\%20 NAWMA\%20STANDARDS.pdf.

Tellman, B. 2002. Invasive Exotic Species in the Sonoran Desert Region. Tucson: University of Arizona Press.

Underwood, E., S. Ustin and D. DiPietro. 2003. Mapping nonnative plants using hyperspectral imagery. Remote Sensing of Environment 86:150-161.

USDA, NRCS. 2007. The PLANTS Database. Baton Rouge, LA: National Plant Data Center. http://plants.usda. gov.

Webster, T.M., J. Cardina and S.J. Woods. 2000. Spatial and temporal expansion patterns of Apocynum cannabinum patches. Weed Science 48:728-733. 
Wittenberg, R. and M.J.W. Cock. 2001. Invasive alien species. How to address one of the greatest threats to biodiversity: A toolkit of best prevention and management practices. Wallingford, Oxon, UK: CAB International. http:// www.cabi-bioscience.ch/wwwgisp/ index.html.
Inventory \& Monitoring Program in Tucson, AZ 85710 during this project, msmauzy@hotmail.com ist with the Office of Arid Lands Studies,

University of Arizona, Tucson, AZ 85719 , 520/626-8582, Fax 520/621-3816,

theresam@u.arizona.edu

Melissa Mauzy served as a Biological Science Technician with the National

Park Service, Sonoran Desert Network
Sarah E. Studd works as a plant biologist for the National Park Service, Sonoran Desert Network Inventory \& Monitoring Program in Tucson, AZ 85710, 520/731-3420x5, sarah_studd@nps.gov 